their patients may be taking "on their own." MacLean's powder is definitely alluded to on pages 87 and 162 , though the formula given on page 162 as "the basis of many popular and efficacious remedies" is far removed from those in common use. Lanette Wax might also find a place in the index, and also as a synonym on page 43 . The much-renowned and widely-used "Calamine Lotion" is not represented in any of its varieties, and the only suggestion of its. existence appears to be that on page 383 in the text, "Calamine (impure zinc carbonate) is an excellent slight astringent for itching skin disease." In a future issue perhaps an inch can be spared for it, although it may be unofficial.

On page 313, top, the formulae for the first two drugs have got transposed, and on the preceding page, fourth line from foot, an $r$ has crept into the word urethane.

\section{DEEP MASSAGE AND MANIPULATION ILLUSTRATED}

By James Cyriax, M.D., B.Ch. Hamish Hamilton Medical Books. London. I944. I5s.

"I read this book with great pleasure. Dr. Cyriax deals with the subject in a very lucid and concise manner, whilst the book is illustrated by many excellent photographs showing the position of the patient and the masseuse for each treatment: in fact after reading the book, with no knowledge of Dr. Cyriax's technique, any masseuse could deal with most of the fibrositic lesions that she is likely to meet in practice.

There are some minor criticisms which are these: Many Physiotherapists would not entirely agree with Dr. Cyriax's statement that fibrositis of the Rhomboid muscles is rare, but that fibrositis of the Levator angulae scapula muscle is common. I seem to spend much time palpating painful lumps in what I have always considered the Rhomboid muscles, but perhaps my knowledge of anatomy as an Orthopaedic Surgeon, is at fault. It would appear that Dr. Cyriax has described four different types of tennis elbow, this at first sight might appear muddling. Surely it would have been wiser to have stated that there are not four types, but four sites of inflamatory processes around the elbow joint which give rise to a syndrome loosely called tennis elbow.

His optimistic prognosis as the result of his frictional massage, permeates the book, though he very wisely indicates those lesions which may need some other form of treatment of manipulative nature.

This book could be read with advantage by any general practitioner interested in rheumatic fibrositis and certainly should be in the hands of every masseuse."

\section{HANDBOOK OF PRACTICAL BACTERIOLOGY}

By T. J. MAcKIE, C.B.E., M.D., D.P.H., and J. E. McCarTNEY, M.D., D.Sc. 7th Edition. E. and S. Livingstone, Ltd. Edinburgh. 1945. 7s. 6d.

The seventh edition of this well-known and established handbook lives up to its subsidiary title, $A$ Guide to Bacteriological Laboratory Work. Six successive editions of this book have, since r925, stood in succession on the reference shelf above the present reviewer's workng bench in his various laboratories, with, as their immediate neighbours on either side, "Muir and Ritchie" and "Stitt." A few months ago his copy of the sixth edition disappeared, along with the rest of his laboratory and all of its equipment, in the dust and smoke of a Hun flying-bomb, and he therefore all the more warmly welcomes its worthy successor-the seventh edition of a book which has been in constant and almost daily use for the past twenty years. When some unusual specimen arrived in the laboratory, and when asked by any of his lab. technicians for instructions as to its appropriate treatment, his reply would often be: "Use so-and-so's method. You'll find the details of it if 'Mackie and McCartney," - - a reply which often saved" much time and brain-fag for all concerned. The book isj thoroughly up-to-date, and contains short, succinct, an $\bar{P}$ understandable instructions for the carrying out of a the more usual and useful standard laboratory method $\$$ and procedures, as well as many of those more recently introduced. It is a reviewer's privilege to apportion; praise or blame or a judicious admixture of these but op this occasion he has searched in vain for errors either of omission or of commission, and even typographical slips are unusually scanty, though "Endamoeba" occurs in the heading on page 423 , the word being spelt elsewhere witkp a " $t$." "Listevella" (pp. I7 and 393) should now b. rendered "Listeria," and "vaccinial" rather than "vace cinal" (P. 62I) is the form preferred by the Journal of Pathology and Bacteriology. "Virucidal" might replace. "viricidal" (p. 44) as probably more correct, though thes $\odot$ various words have not yet found their way into the Shorter Oxford English Dictionary. The misleading and obsolete name of " $B$. influenzae" or "the influenza bacif? lus" for Peiffer's Hamophilus might now be discarded altogether. It is rather a relief to be able to read abou震. $B$. typhosus, B. diphtheria, and B. tuberculosis or typhoiojo diphtheria, and tubercle bacilli, in place of the ultrap scientific Eberthella, Corynebacterium, and Mycobacteriunis which now blossom on the pages of the journals and fot which, like jazz and crooning, we are indebted to Americai The reviewer is quite content to see these cumbrous terms relegated to the preliminary list on page I4 entitled "Newer Classification and Nomenclature," or put in brackets after the well-established names which have been usedð̈or these organisms by many generations of quite volle educated bacteriologists. Our authors are semi-apologetig for their war-time device of putting much of their matter into an "Appendix," but this device saves the publishers and printers, and incidentally the purchasere of the book, considerable additional expense, and enaGles. its readers to find much of this newer matter focusie here, for example the latest available information about the "antibiotic" or "bacteriostatic" action of the "⿹l一 phonamides and penicillin, fluorescence and electros microscopy, and the newer methods of preparing specia culture-media, e.g. for the differentiation and identifica? tion of the various types of diphtheria bacilli and for the cultivation of anaerobes. In Chapter XXIV there much useful and interesting information about viral ina fections, and on page 579 of the section on Malaria, we note the up-to-date inclusion of Plasmodium ovale. W heartily approve of the suggestion on page 6r9 that the "elementary bodies" of vaccinia and variola should, i recognition of their discovery in 1886 by Dr. John B. Buis甲 of Edinburgh, now be termed Buistia pascheni.

We cordially welcome this seventh edition of a book packed with up-to-date information which makes it as indispensable in a bacteriological laboratory as are McCartney's screw-capped bottles and culture-tubes.

\section{MODERN TREATMENT YEARBOOK, 1944}

Edited by Cecil P. G. Wakeley, C.B., D.Sc., F.R.C.\$ Pp. viii and 2II; I7 plates, 55 illus.: The Medica Press and Circular: London. I944. Price I5s. net?

This is the tenth volume of this series of yearbooks. and maintains the high standard already set. There are forty-two articles altogether by specialists in their various spheres, half of the number being on ordinary peace-time subjects, and the other half on War Medicine and Surgerpo four of the latter being on Rehabilitation of Fractures $\mathrm{mod}$ the Royal Navy; of Joint Injuries; in General Hospitalg and in Neuro-psychiatry. Altogether a stimulating ang informative book. 